\title{
A GENUS AND TWO SPECIES OF INSECTS NEIV FOR PUERTO RICO
}

A genus and two species of insects not previously reported from Puerto Rico are announced here. The specimens were identified by Drs. A. Stone, C. F. W. Muesebeck, and B. D. Bucks of the USDA Entomology Research Division at Beltsville, Md.

Scatopse fuscipes Mg.-Order Diptera, Fam. Scatopsidae under P.R. Ac. Nos. 14-63 was first collected by George C. Jackson at Fortuna Agricultural Experiment Substation, P.R., and was very numerous on Epidendrum anceps April 22, 1963.

Hormius vulgaris Ashm.-Order Hymenoptera, Fam. Braconidae under P.R. Ac. Nos. 20-63 was first collected by Dr. Mario E. Perez at the Gurabo Substation, P.R., parasitizing the sphinx caterpillar, Cocytius antaeus antaeus (Drury), feeding on Annona muricata leaves, in May 1963. It was found with other parasites namely: A panteles congregatus (Say), and $A$ panteles sp.

Eunotus sp.-Order Hymenoptera, Fam. Pteromalidae. This genus under P.R. Ac. Nos. 10-63 was first collected by S. Medina Gaud in a greenhouse at the Río Piedras Agricultural Experiment Station. The insect was reared in the laboratory from the scale insects, Cerococcus sp. and Saissetia nigra, attacking plants of Hibiscus rosa-sinensis $\mathrm{L}$. 